\title{
NIKOLAJ KAVÁSILAS A KRÍZA BYZANTSKEJ SPOLOČNOSTI V 14. STOROČ́́ 1
}

\author{
Nicholas Kabasilas and the Crisis of Byzantine Society in the 14th Century
}

\author{
Ján Zozul'ak
}

DOI: 10.17846/CL.2020.13.2.89-98

\begin{abstract}
ZOZULAK, Ján. Nicholas Kabasilas and the Crisis of Byzantine Society in the 14th Century. The aim of the article is to present the life and work of Nicholas Kabasilas, one of the forefront figures of the fourteenth-century Eastern Roman (Byzantine) Empire. Not much information has survived on the life of Nicholas Kabasilas, despite the fact that he was an advisor to the Emperor John VI Kantakouzenos from 1347 to 1354 and significantly influenced the development during his era which was shaken by two very crucial events: Hesychast controversy and the fight for the throne after the death of Andronikos III between Alexios Apokaukos and John VI Kantakouzenos. Misunderstandings and conflicts between Hesychasts and Anti-Hesychasts lay in different starting points and are related to the issue of the humanistic and patristic revival in Byzantium. Greek monk Barlaam of Calabria got into conflict with traditional Byzantine views and he ruled out the possibility of real communion with God, therefore he opposed Hesychasts. The defence of Hesychasts was undertaken by Gregory Palamas, the paramount representative of Byzantine thought and the leading figure of Hesychasm who reacted to the gnosiological issue of God on the basis of distinction between unattainable Divine substance and attainable uncreated Divine energies. Kabasilas did not enter open conflict like Gregory Palamas, but he focused more on the clarification of anthropological questions. He also paid attention to the social issues and problems of common people in need who were fighting for social justice. He criticized usury and injustice of the rich, which led people to poverty and, in turn, violence.
\end{abstract}

Keywords: Nicholas Kabasilas, Byzantine Empire, humanist revival, patristic revival, Hesychast Controversy

\section{Úvod}

Posledné tri storočia existencie Východorímskej (Byzantskej) ríše boli kritickým obdobím, plným nepokojov a rozkolov tak v politickej, ako aj v cirkevnej rovine. Na jednej strane ju ohrozovali vonkajší nepriatelia: Frankovia, Srbi, Bulhari a Turci, na druhej strane sa ríša zmietala v nepokojoch a sporoch o cisársky trón. Obnovená Byzancia v roku 1261 už nebola slávnou ríšou minulosti, ale malým štátnym útvarom s armádou, ktorá nestačila na jej obranu. Vel'ké ekonomické problémy, sociálna nerovnost’ a kríza hodnôt postupne viedli k zložitej spoločenskej situácii, ktorá vyvrcholila pádom Konštantínopola v roku 1453 a zánikom viac ako tisíc rokov trvajúcej ríše.

Napriek politickému a hospodárskemu úpadku bolo 14. storočie obdobím humanistickej a patristickej obrody, ale zároveň aj obdobím isychastických (hesychastických) sporov.

Táto práca bola podporovaná Agentúrou na podporu výskumu a vývoja na základe Zmluvy č. APVV-16-0116. 
V Konštantínopole a Thessalonikách pôsobili významní filozofi, teológovia, právnici, lekári, matematici a znalci prírodných vied, ktorí konštruktívne reagovali na rôzne filozofické, teologické a filologické otázky, rozvíjali prírodné vedy a filozofiu, venovali sa umeniu a aktívne sa podielali na spoločenskom a politickom živote Byzantskej ríše. Neobvyklý rozmach zaznamenalo byzantské umenie, ktorým bol v tomto období výrazne ovplyvnený aj Balkán, predovšetkým Srbsko. Zároveň došlo k stretu východnej a západnej kultúry, čo spôsobilo zvýšený záujem byzantských filozofov, teológov a politikov o západné filozofické a teologické myšlienky. Mnohí byzantskí vzdelanci sa snažili pochopit západnú kultúru a reagovali na rôzne otázky.

Uprostred tejto duchovnej klímy žil a pôsobil byzantský intelektuál Nikolaj Kavásilas, ktorý patril k významným osobnostiam Byzantskej ríše v 14. storočí, ako je zrejmé z jeho života i diela. V našej štúdii predstavíme život tohto vel'kého myslitela, ktorý bol na jednej strane búrlivý kvôli cirkevným a politickým otrasom, na druhej strane cnostný a nepozorovaný.

\section{Pôvod Nikolaja Kavásila}

O živote Nikolaja Kavásila sa nezachovalo vela informácií napriek tomu, že žil v Thessalonikách i Konštantínopole, výrazne ovplyvnil svoju dobu a podstatne prispel k vítazstvu isychastov v Byzantskej ríši. Nie je známy presný rok jeho narodenia ani smrti, pretože sa nezachoval jeho životopis. Niekol'ko stručných informácií, ktoré o ňom máme, pochádza z jeho vlastných diel a dobových historických prameňov.

Na základe existujúcich informácií vieme, že Nikolaj Kavásilas sa narodil okolo roku 1322 v Thessalonikách, druhom najvýznamnejšom meste Byzantskej ríše. Dokazuje to list, ktorý v roku 1351 poslal Anne Palaiologine, správkyni Thessaloník. Píše v ňom, že ešte nedovŕšil tridsiaty rok života (Guilland 1935, 274). ${ }^{2} \mathrm{~V}$ roku 1353 sa ako laik stal jedným z troch kandidátov na volbu nového konštantínopolského patriarchu a podla cirkevných kánonov musel mat' najmenej tridsat’ rokov (Christou 1979, 8).

Jeho matka pochádzala z bohatej a významnej byzantskej rodiny Kavásilas. ${ }^{3}$ Bola sestrou thessalonického arcibiskupa Níla Kavásila (1361 - 1363). Priezvisko jeho otca bolo Chamaetós, ktoré sa v prameňoch spomína zriedka. Obaja rodičia sa vyznačovali cnostným životom a poskytli mu krestanskú výchovu. Otec bol hlboko veriaci a zbožný človek, ako je zrejmé z korešpondencie, ktorú s ním viedol počas svojho štúdia v Konštantínopole.

Základné vzdelanie dostal v Thessalonikách pod vedením strýka Níla Kavásila, horlivého podporovatela Gregora Palamu. Z toho vyplýva, že Nikolaj bol vychovávaný v duchovnom prostredí isychastov, v ktorom významné miesto zohrával Isídor, neskôr konštantínopolský patriarcha (1347 - 1349). Isídor bol žiakom Gregora Sinajského (1255 - 1346), otca a učitela ticha (jovxía). Žil v Thessalonikách a duchovne viedol hlavne mladých ludí. Duchovným otcom Nikolaja Kavásila bol Doróteos Vlatís, žiak a verný nasledovatel' Gregora Palamu a neskôr thessalonický arcibiskup (1371 - 1379).

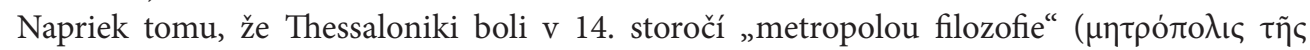

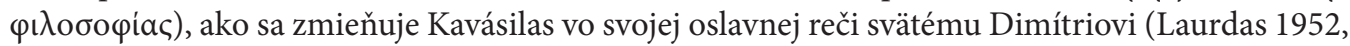
108-109), a boli tam významné školy, na podnet svojho strýka Níla odišiel do Konštantínopola, aby na Filozofickej škole pokračoval v štúdiu (1335/7 - 1342) filozofie, rétoriky, teológie, práva

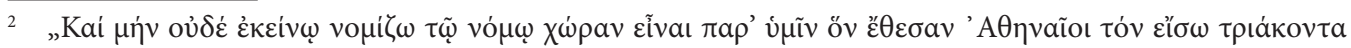

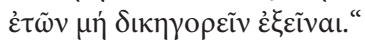

3 Podrobnejšie o genealógii tejto rodiny pozri Angelopoulos 1977, 367-396. 
a prírodných vied. Na základe jeho listov a krátkych štúdií z tohto obdobia je zrejmá jeho láska k literatúre i spisovatel'ský talent.

\section{Isychastické (hesychastické) spory}

Na konci štúdia Nikolaja Kavásila v roku 1341 Konštantínopolom otriasli dve udalosti: isychastické spory a boj o spravovanie uvolneného cisárskeho trónu po smrti Andronika III. (1328 - 1341) medzi Aléxiom Apokaúkom a Jánom VI. Kantakuzinom.

Isychastické spory trvali od roku 1334, ked’ grécky mních Varlaám (Barlaám) z Kalábrie v Itálii (okolo 1290 - 1348) uverejnil dielo Proti latiníkom (Contra Latinos), do roku 1351, ked'bol zvolaný snem, na ktorom cisár Ján VI. Kantakuzinós, patriarcha Kállistos (1350 - 1353, 1355 - 1363) a další

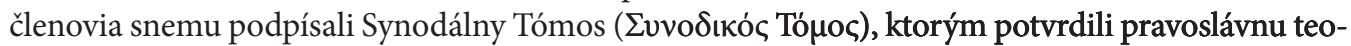
lógiu, ako ju vyjadril Gregor Palamas a isychasti. Neskôr ho podpísal aj Ján V. Palaiologos a Matúš (Matthaíos) Kantakuzinós.

Varlaám (Barlaám) otvoril vážne filozofické a teologické otázky, ktoré viedli k isychastickým sporom. Mal vynikajúce vzdelanie a hoci sa jeho myslenie zo začiatku zhodovalo s byzantskou tradíciou, náklonnost' k západnej dialektike zásadne zmenila jeho postoj a dvojitú metódu predošlých byzantských myslitelov nahradil scholastickou dialektickou metódou, čím sa dostal do rozporu $\mathrm{s}$ tradičným byzantským chápaním. Varlaám, navyše, spochybňoval skúsenost’ teoptie a vylučoval možnost’ skutočného spoločenstva človeka s Bohom, preto sa postavil proti isychastom, ktorí prostredníctvom asketického spôsobu života a ustavičnej modlitby dochádzali k videniu nestvoreného svetla. Bol hlavným nositelom západného renesančného ducha, ktorého základnými charakteristickými znakmi bol autonómny humanizmus, ktorý predpokladal človeka odtrhnutého od Boha, racionalizmus, ktorý uctieval ludský rozum a poznanie, odcudzenie teológie od životnej skúsenosti Cirkvi.

Obrany isychastov sa ujal Gregor Palamas (1296 - 1359), vrcholný predstavitel' byzantského myslenia a najvýznamnejšia osobnost isychazmu, ktorého základným rysom bola snaha o dosiahnutie dokonalosti človeka. Palamas svojimi formuláciami upevnil byzantskú filozofickú a teologickú tradíciu. Jeho prácu môžeme označit za syntézu celého byzantského myslenia. Medzi Palamove najdôležitejšie texty patria traktáty a listy, ktoré obsahujú dôležitý filozofický, teologický a historický materiál. V triádach Reči na obhajobu isychastov (Palamas 2010, 313-694)

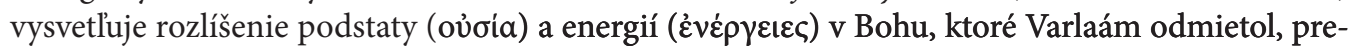
tože trval na absolútnej neprístupnosti a nepoznatelnosti Boha a akékolvek tvrdenie o videní Boha považoval za opis rôznych ludských pocitov. Zároveň „odmietal používanie sylogizmov v teológii a jeho základnou tézou bol špecifický teologický a v podstate aj všeobecný agnosticizmus, ktorý vychádzal z filozofického chápania negatívnej teológie“ (Milko 2009, 198).

Gregor Palamas rozvinul originálne myslenie a na základe nových filozofických východísk objasnil gnozeologické otázky. Zároveň vysvetlil chápanie vztahu medzi filozofiou a teológiou v Byzancii. Na podnet antiisychastov, ktorí používali dialektickú metódu a vychádzali zo stvorenej reality, objasnil, prečo sa isychasti striktne držia dvojitej metódy, podla ktorej poznávat’ Boha je možné najprv prostredníctvom účasti $(\mu \varepsilon \dot{\varepsilon} \theta \varepsilon \xi ı)$ ) na Božom osvietení a až potom prostredníctvom filozofického skúmania. Zdôraznil, že Božia podstata je pre človeka neprístupná a nepoznatelná, ale človek pri zbožštení ( $\theta \varepsilon \dot{\varepsilon} \omega \sigma \iota \varsigma)$, konečnom cieli a zmysle života, dochádza do reálnej účasti v Bohu prostredníctvom Božích energií, ktoré sú nestvorené, ale líšia sa od podstaty. Isychasti sa snažili vidiet Boha prostredníctvom modlitby a askézy, preto teológiu používali ako prostriedok priblíženia sa $\mathrm{k}$ nestvorenému Bohu. Antiisychasti sa na základe racionalistického prístupu domnievali, že poznanie Boha je možné na základe schopností ludskej mysle, preto teológiu 
považovali za predmet skúmania. Je zrejmé, že nedorozumenia medzi isychastami a antiisychastami spočívali v odlišných východiskách a súvisia s problematikou humanistickej a patristickej obrody v Byzancii.

\section{Humanistická a patristická obroda}

Počiatky rozvoja humanistickej obrody v Byzancii siahajú k filozofovi Michalovi Psellovi a jeho žiakovi Jánovi Italovi. Michal Psellós (1018 - 1078) zanechal bohaté literárne dielo, ktoré jasne odráža byzantskú filozofiu, dialektiku, rétoriku, gramatiku, geometriu, aritmetiku, etiku, psychológiu, biológiu, botaniku, zoológiu a dalšie vedy. Tento polyhistor mal jedinečnú schopnost̉ zahrnút do svojho myslenia celú byzantskú kultúrnu tradíciu a jej syntézou významne prispel k rozvoju byzantskej vedy a filozofie. Študoval Aristotela, Platóna, Plotína, Porfýria, Iamblicha i Prokla a právom mu patril titul najvyšší filozof ( $\tilde{\pi} \pi \alpha \tau \varsigma \varsigma \tau \tilde{\omega} v \varphi \iota \lambda o \sigma o ́ \varphi \omega v)$. Najviac sa preslávil obnovením platónskych a novoplatónskych štúdií a niektoré významné novoplatónske diela poznáme len z jeho komentárov. Michal Psellós bol vedcom, filozofom i rétorom (Papaioannou 2013, 29), ku ktorému prichádzali študovat̉ mnohí učenci, pretože obdivovali jeho znalosti. Zároveň bol teológom, ktorý si pri svojom uvažovaní plne uvedomoval význam dvojitej metódy byzantských myslitelov, preto „charizmatická teológia bola pre neho životom, vedecké pozorovanie jednotlivých častí poznatelných javov niečím samostatným a filozofia zmysluplným skúmaním každého poznania“" (Matsoukas 2010, 447-448).

Ján Italos (okolo 1025 - 1082) bol rovnako výraznou osobnostou. Po rýchlej kariére tiež dostal titul najvyššieho filozofa a stal sa nástupcom svojho učitela Michala Psella. Pochádzal z Kalábrie, ale v Konštantínopole našiel vedecké a filozofické prostredie, ktoré hladal, preto sa začal venovat’ komentovaniu novoplatónskych a aristotelovských textov. Filozofiu nepoužival v duchu zaužívanej tradície byzantských myslitel’ov a na rozdiel od svojho učitela sa nepridržiaval dvojitej metódy, podla ktorej filozofia skúma otázky stvorenej reality. V dôsledku toho nerozlišoval charizmatickú teológiu od vedeckej a krestanskú skúsenost̉ nahradil filozofickými kategóriami. Platónsku filozofiu chápal ako základný prvok teológie, ktorá je len „pokračovaním filozofie v inom kontexte“ (Milko 2009, 187).

Humanistickú obrodu do vel'kej miery podporoval cisár Michal VIII. Palaiologos ${ }^{4}$ a do popredia sa čoraz viac dostávalo humanistické vzdelávanie. Učenie Platóna a Aristotela sa začalo vyučovat' na všetkých vysokých školách v Byzancii a ich myslenie výrazne ovplyvňovalo intelektuálne kruhy. Mnohí byzantskí humanisti boli ovplyvnení západným aristotelovským myslením a preukazovali osobitnú náklonnost’ k intelektuálnemu riešeniu teologických otázok. Antická filozofia, predovšetkým Aristotelova, sa pre nich stala základným kritériom interpretácie rôznych teologických otázok. Napriek tomu byzantský humanizmus nebol zameraný protinábožensky, ako tomu bolo na Západe, hoci Božiemu zjaveniu pripisoval sekundárny význam.

Latinská scholastická teológia sa v Byzancii stala známou vd’aka prekladom najvýznamnejších diel západných spisovatelov Augustína ${ }^{5}$ a Tomáša Akvinského ${ }^{6}$, ktoré do gréckeho jazyka v 14. storočí zrealizovali Maxim Planúdis a bratia Dimítrios a Próchoros Kydónis. Maxim Planúdis (okolo 1255 - 1305), filológ, matematik a astronóm, patril k najväčším vzdelancom doby. Pokúsil sa pozdvihnút vzdelanie prostredníctvom matematiky a istým spôsobom odvrátit nebezpečenstvo

4 Michal VIII. Palaiologos v roku 1261 oslobodil Konštantínopol a začalo sa obdobie kultúrneho rozmachu, nazývané byzantská renesancia.

5 O prekladoch Augustínových diel do gréckeho jazyka pozri C. Kugea (1909, 106-146); M. Rackl (1924, 1-35); M. Gigante (1958, 173-194).

6 O prekladoch diel Tomáša Akvinského do gréckeho jazyka pozri S. Papadopoulos (1967, 27-116). 
prichádzajúceho zániku Byzantskej ríše. Napísal učebnice gramatiky, vydal Ptolemaiovu Geografiu a texty antických autorov s komentármi. Jeho literárna činnost’ sa neobmedzovala len na gréčtinu, ale naučil sa aj latinský jazyk, z ktorého preložil texty Cicera, Macrobia, Augustína, Boétia a Tomáša Akvinského. K jeho najdôležitejším prekladom patrí Augustínove dielo De trinitate. Planúdis sa prostredníctvom prekladov stal sprostredkovatelom medzi východným a západným svetom a môže byt’ považovaný za predchodcu obrody gréckych klasických štúdií na Západe.

Dimítrios Kydónis (okolo 1324 - 1397) preložil dielo Summa theologiae Tomáša Akvinského a diela Augustína i Ambróza. Napriek náklonnosti k západnej teológii v jeho filozofickom a teologickom diele dominuje byzantský spôsob myslenia. Rovnaký postoj zaujal jeho brat Próchoros Kydónis (okolo 1333 - 1369/70). V tomto zložitom období sa obaja bratia snažili stat mostom medzi Východom a Západom.

Prostredníctvom uvedených prekladov sa do Byzancie dostala Augustínova teológia, ktorá je v podstate syntézou krestanstva a platonizmu - novoplatonizmu, ako aj scholastická teológia Tomáša Akvinského, ktorá je syntézou krestanstva a aristotelizmu. Latinská teológia medzi niektorými byzantskými humanistami našla odozvu, ale medzi mnohými vyvolala negatívne reakcie.

Protikladnou voči humanistickej obrode bola patristická obroda na čele s myslitel’mi, ktorí

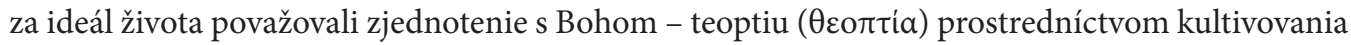
cností cez askézu a duchovnú ostražitost' ( $v \tilde{\eta} \psi(\varsigma)$. Bol to hlavný teologický prúd 14. storočia, kto-

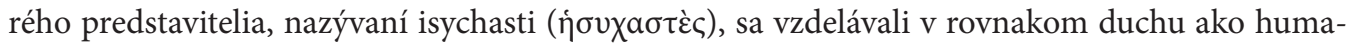
nisti s tým rozdielom, že z rôznych filozofických systémov si prepožičiavali len niektoré vonkajšie elementy, pričom sa odvolávali na Božie zjavenie. Rozdiel medzi humanistickou a patristickou obrodou spočíval v odlišných východiskách, čo viedlo k stretu byzantskej a latinskej scholastickej teológie (Papadopoulos 1970, 46). Logickým dôsledkom tohto stretu bol konflikt medzi isychastami a antiisychastami.

Antiisychasti boli väčšinou humanisti, ktorí vychádzali z antropologických predpokladov západných myslitelov, nadmerne zdôrazňovali ludský rozum a opierali sa o aristotelizmus. Isychasti zdôrazňovali možnost̉ videnia nestvorených energií ako Božieho (Táborského) svetla a vysvetlovali proces účasti človeka na nestvorených Božích energiách prostredníctvom ustavičnej modlitby a očistovania od vášní. Tak rozvíjali patristickú tradíciu autentického byzantského humanizmu a opierali sa o byzantskú antropológiu, ktorej cielom je spása človeka a zjednotenie s Bohom prostredníctvom videnia ( $\theta \varepsilon \omega \rho i ́ a)$ Božej slávy.

\section{Reakcia Nikolaja Kavásila na krízu byzantskej spoločnosti}

Neustále vojny a vnútorné konflikty v 14. storočí priniesli politické i ekonomické otrasy a neistotu lud’om, ktorí pri snahe uniknút z krízy zobrali zodpovednost’ do svojich rúk, pretože sa domnievali, že tak zachránia spoločnost'. V dôsledku toho v roku 1341 vypukla občianska vojna, ale mladý Nikolaj Kavásilas sa pravdepodobne aktívne nezapojil do bojov. Nasledujúci rok sa vrátil do Thessaloník, kde panoval vel'ký politický, spoločenský a náboženský chaos, horší ako v hlavnom meste. Mesto ovládli zelóti, ktorí sa postavili proti Kantakuzinovi a vyzývali obyvatelov k ozbrojenému povstaniu proti bohatej aristokracii, ktorej pripisovali zodpovednost' za všetky útrapy. Zvrhli právny poriadok a dopustili sa násilných činov. Išlo o vzburu ekonomicky a spoločensky nižších tried, ktoré v júli 1342 ovládli mesto. V dôsledku toho došlo k izolácii Thessaloník a život obyvatelov sa vel’mi skomplikoval, čo viedlo väčšinu obyvatel’ov k hladaniu dohody s Kantakuzinom. V roku 1345 boli Nikolaj Kavásilas a Geórgios Farmákis poslaní do Vérie s cielom upokojit’ situáciu. Namiesto nastolenia pokoja zelóti začali nelútostné vraždenie thessalonickej aristokracie. Len niektorí z nich sa zachránili, medzi nimi aj Nikolaj Kavásilas, ktorého ludia ukryli v studni. 
Po týchto tragických udalostiach Kavásilas upriamil pozornost̉ na spoločenské problémy, ktoré vyvolali násilnosti, a reagoval na požiadavky prostého ludu, ktorý bojoval za nastolenie spravodlivosti v spoločnosti. Citlivo a s pochopením sa snažil nájsț riešenie danej situácie, preto napísal dva spisy, ${ }^{7}$ v ktorých je cítit jeho súcit a horlivost pre spravodlivost' a pravdu. V týchto textoch kritizoval úžerníctvo a nespravodlivost' bohatých, ktoré viedli ludí k chudobe a násiliu. Navrhol zákony, ktoré by mohli zmiernit situáciu trpiacich a neštastných ludí. $\mathrm{V}$ tejto súvislosti je dôležité upozornit, že Nikolaj Kavásilas bol jedným z mála byzantských myslitelov, ktorí sa zaoberali sociálnymi problémami svojej doby.

\section{Nikolaj Kavásilas vo funkcii poradcu cisára}

V roku 1347 sa skončil konflikt medzi Aléxiom Apokaúkom a Jánom VI. Kantakuzinom a za cisára bol korunovaný Kantakuzinós. Jeho vítazstvo bolo zároveň vítazstvom isychastov. V tejto atmosfére zmierenia Dimítrios Kydónis (okolo 1324 - 1397) pravdepodobne na príkaz nového cisára pozval Nikolaja Kavásila do Konštantínopola, kde sa začala jeho politická kariéra. Cisár si tak vysoko cenil jeho schopnosti, že spolu s Dimítriom Kydónisom ho vymenoval za svojho hlavného poradcu. Túto funkciu Nikolaj vykonával od roku 1347 do roku 1354 (Kavasilas 2004, 14).

Novým konštantínopolským patriarchom sa zhodou okolností stal Isídor (1347 -1349), jeden z jeho prvých učitelov v Thessalonikách. V septembri 1347 Nikolaj Kavásilas sprevádzal novozvoleného arcibiskupa Gregora Palamu po mori na intronizáciu do Thessaloník, ale zelóti im znemožnili vstup do mesta, preto odišli na Svätú Horu Atos, kde zostali jeden rok a potom sa vrátili do Konštantínopola.

Na sneme v roku 1351 definitívne zvítazilo isychastické učenie Gregora Palamu. Odvtedy Dimítrios Kydónis viac inklinoval k Palaiologovi a stal sa protivníkom isychazmu. Nikolaj Kavásilas viac inklinoval ku Kantakuzinovi a zaujal odlišný postoj k isychazmu, ktorý prijal bez zvláštnej obhajoby či polemiky. Dôvodmi ich odlišného postoja boli rozdielne dogmatické a cirkevno-politické východiská.

Isychastickú tradíciu Kavásilas dokázal majstrovsky využit pri písaní svojich textov a prostredníctvom úvah o nestvorených Božích energiách sa mu vynikajúcim spôsobom podarilo objasnit’

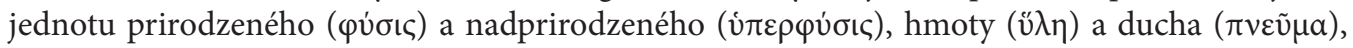
tela $(\sigma \tilde{\omega} \mu \alpha)$ a duše $(\psi v \chi \eta ்)$. Grécke vzdelanie a kultúru formoval prostredníctvom byzantského

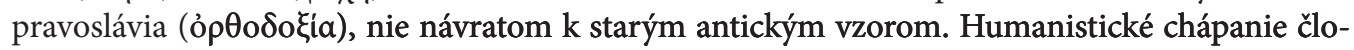
veka obohatil o progresívne zdokonalovanie, ako je zrejmé z jeho najdôležitejšieho diela $O$ živote $v$ Kristu, v ktorom objasňuje zjednotenie človeka s Bohom prostredníctvom Božej ikonómie. V Kavásilových textoch nachádzame nielen koncentrovanú podobu celého byzantského myslenia, ale aj reakciu na agnostické postoje antiisychastov.

Koncom 14. storočia sa v Byzancii odohrávali dramatické udalosti a turecká hrozba viedla byzantských politikov $\mathrm{k}$ snahe zbližit východný a západný svet s cielom získat pomoc od rímskeho pápeža. V postoji k Západu nepanovala jednota, preto vznikli dva smery: zástancovia a odporcovia jednoty s Rímom. Prví podporovali jednotu so západnou cirkvou a stáli po boku cisárov usilujúcich o jednotu. Predstavitelia druhého smeru boli presvedčení, že jednota znamená podriadenie sa pápežovi. Nikolaj Kavásilas sa v otázke vztahov s rímskokatolíckou cirkvou vyjadril za zbližovanie bez dogmatických či ekleziologických ústupkov, ale Dimítrios Kydónis trval na bezpodmienečnom zjednotení s rímskym pápežom. Kantakuzinós bol presvedčený, že otázka cirkevných vztahov je v právomoci Cirkvi, preto navrhol zvolanie všeobecného snemu na neutrálnej pôde

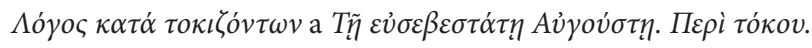


za účasti všetkých biskupov Východu i Západu. Zdá sa, že mu to poradil Nikolaj Kavásilas, ktorý mal v tom čase už vel'kú autoritu.

\section{Koniec politickej kariéry Nikolaja Kavásila}

V roku 1354 sa cisárskeho trónu zmocnil Ján V. Palaiologos a Kantakuzinós sa stal mníchom. Vtedy sa Nikolaj Kavásilas prestal venovat politickým záležitostiam a po boku patriarchu Filótea Kókkina (1353 - 1355, 1364 - 1376) sa pravdepodobne zaoberal len cirkevnými otázkami. V roku 1362 sa vrátil do Thessaloník a pokúsil sa dostat pod kontrolu čast̉ svojho velkého majetku, ktorý mu zostal po uchvátení zelótov a Srbov. Ked’ tam prišiel, dozvedel sa o smrti svojho otca, ktorý krátko predtým zomrel. Nasledujúci rok zomrel aj jeho strýko, thessalonický arcibiskup Nílos. Jeho matka sa po týchto udalostiach stala mníškou v monastieri svätej Teodory v Thessalonikách (Christou 1979, 11). Je dost̉ pravdepodobné, že v tom čase sa aj Nikolaj stal mníchom (Angelopoulos 1968, 67-74), čo sa zhoduje s jeho návratom do Konštantínopola v roku 1364 a druhým nástupom Filótea na trón konštantínopolského patriarchu. Oslobodený od verejných a politických záležitostí posledné roky života prežil v tichu ( $\varepsilon v$ jंovxịa). Na základe svedectiev jeho súčasníkov sa usadil v jednom z monastierov v Konštantínopole, pravdepodobne v monastieri svätého Juraja v Mangane. Neexistujú informácie o tom, či bol vysvätený za kňaza, hoci jeho znalosti a spôsob vyjadrovania $\mathrm{v}$ dvoch hlavných dielach naznačujú kňazský stav.

Posledné biografické údaje sa zachovali v liste, ktorý mu adresoval Jozef Vryénios (1350 -

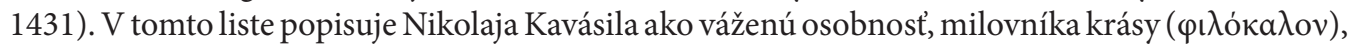

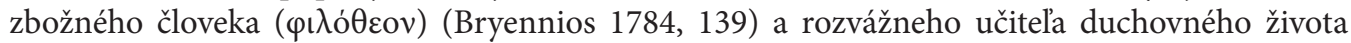
(Nellas 1984, 84). Vyzdvihuje jeho múdrost’ a rozvážnost', nazýva ho blaženým nielen pre jeho

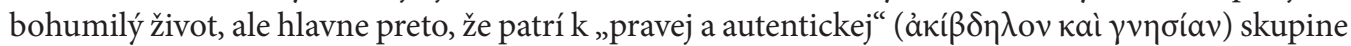

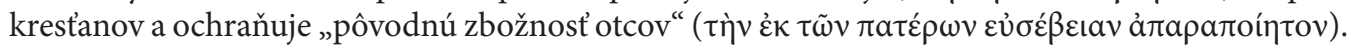
V liste nachádzame roztrúsené pocity úcty, obdivu a lásky: „Kto by t’a neobdivoval pre tvoje cnosti? Kto by t’a nemal rád? Nuž, aj my t’a milujeme, ale pred nami t’a miluje Boh, ktorého si napodobňoval v ludomilnosti“ (Tomadakis 1959, 31-32).

Na základe tohto listu je zrejmé, že Nikolaj Kavásilas v pokročilom veku bojoval za pravú vieru v období sporov medzi tými, ktorí zastávali jednotu s Rímom a tými, ktorí sa postavili proti tejto jednote. Patriarcha Filóteos Kókkinos sa snažil podporovat lud v pravoslávnej viere, zatial čo cisár Ján V. Palaiologos so svojím spolupracovníkom Dimítriom Kydónisom a dalšími poprednými predstavitelmi sa nachádzali na Západe a vyjednávali o zjednotení s rímskokatolíckou cirkvou.

Viac informácií o živote a pôsobení Nikolaja Kavásila sa nezachovalo. Nie je známy ani rok jeho smrti, ale posledný list, ${ }^{8}$ ktorý mu napísal cisár Manuel II. Palaiologos (1350 - 1425), umožňuje predpokladat', že zomrel po roku 1391.

\section{Záver}

Isychastické spory v Byzancii vyvolali nepokoje, ale zároveň vytvorili predpoklady pre rozkvet autentického cirkevného života i myslenia. Odhalili tiež rozdiely medzi byzantskou a latinskou teológiou, ktoré boli príčinou nepriatelstva medzi gréckou a latinskou cirkvou od schizmy v roku 1054. Tieto rozdiely v byzantských intelektuálnych kruhoch v 14 . storočí nadobudli podobu dlhotrvajúceho konfliktu medzi tými, ktorí si z politických dôvodov želali jednotu s rímskokatolíckou cirkvou za akúkolvek cenu, aj ústupkami v otázkach viery, a tými, ktorí v žiadnom prípade neboli

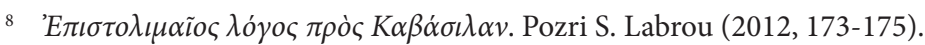


ochotní obetovat svoju pravoslávnu vieru. Počas týchto sporov najvýznamnejší byzantskí intelektuáli napísali vynikajúce diela, medzi ktorými nezastupitelné miesto majú texty Nikolaja Kavásila z posledného obdobia jeho života: Reči $O$ živote $v$ Kristu, Výklad svätej liturgie, tri exegetické diela o videniach proroka Ezechiela, Reči o utrpení a vystúpení na nebo Pána, Reči o narodení, zvestovaní a zosnutí Presvätej Bohorodičky. Kvalitu Kavásilových diel vysoko hodnotí Geórgios Gennádios Scholários (okolo 1400 - 1472), ktorý vyzdvihuje autentickost’ jeho myslenia a hovorí o ňom, že je „ozdobou Kristovej Cirkvi“.9

Nikolaj Kavásilas vynikajúco poznal predošlých byzantských myslitelov, problematiku a filozofické prúdy svojej doby, ale neprichádzal do otvoreného konfliktu ako Gregor Palamas, ktorý reagoval na gnozeologický problém Boha na základe rozlíšenia medzi neprístupnou Božou podstatou a prístupnými nestvorenými Božími energiami. Pozornost' sústredil na objasnenie antropologických otázok ${ }^{10}$ a opakovane zdôrazňoval, že poznanie Boha je možné prostredníctvom skúsenosti, ktorú človek získava cez sväté tajiny. Vo svojom najzrelšom diele $O$ živote $v$ Kristu, v ktorom je cítit jeho vlastnú duchovnú skúsenost', nepriamo, ale jasne odpovedá na odcudzenie teológie od životnej skúsenosti Cirkvi. Autonómny humanizmus a antropocentrizmus konfrontuje so životom v Kristu ako autentickým životom človeka, ktorý nie je ludský, ale boholudský, pretože jeho meradlom nie je starý, ale nový človek - Kristus: „Spasitel’ prvý a jediný svojím étosom a životom ukázal, kto je pravdivým a dokonalým človekom" (Kavasilas 1865, 680C).

Nikolaj Kavásilas vel’mi dobre poznal podstatu krestanskej viery, bol skúsený v duchovných zápasoch a jasne formuloval antropologickú problematiku. Ked' hovorí o živote v Kristu, nemoralizuje, ale analyzuje krestanskú ontológiu. Život v Kristu podla neho nie je formálnym uplatňovaním Božích prikázaní, ale ontologickou obnovou človeka prostredníctvom kultivovania cností (Kavasilas 1865, 684CD), pretože duchovne obnovený človek má možnost’ okúsit blaženost' budúceho života už v terajšom živote.

\section{REFERENCES}

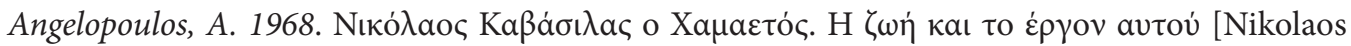
Kavasilas the Hamaetos. His Life and Work]. Thessaloniki.

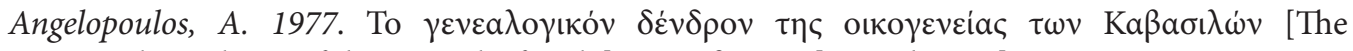

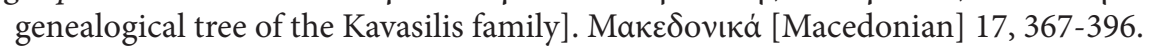

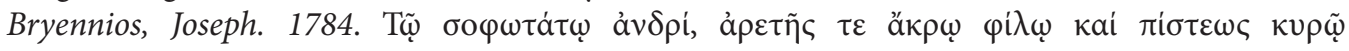

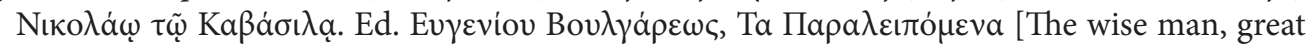
friend of virtue and faith, to Nikolaos Kavasilas. Ed. Eugenios Bulgarian, The Missing]. Leipzig.

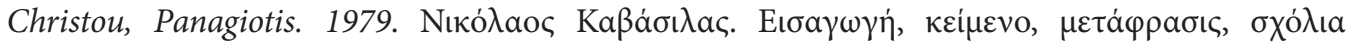

[Nikolaos Kavassilas. Introduction, text, translation, comments]. In $\Phi \iota \lambda$ oк $\alpha \lambda i \alpha \tau \omega \nu \nu \eta \pi \tau \iota \kappa \omega \nu$

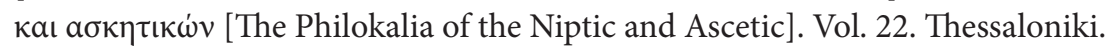

Gigante, Marcello. 1958. Ciceronis somnium Scipionis in graecum a Maximo Planude translatum. La Parole del Passato, 59-60, 173-194.

Gouillard, Jean. 1967. Le Synodikon de Lorthodoxie: Édition et Commentaire. Travaux et Mémoires 2. Paris, 1-316.

Guilland, R. 1935. Le traité inédit «Sur l’usure» de Nicolas Cabasilas (extr. des Mélanges Sp. Lampros). Athens, 269-277.

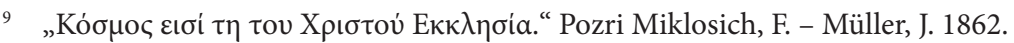

10 Podrobnú analýzu byzantskej antropológie na základe textov Nikolaja Kavásila pozri P. Nellas (1995).
} 


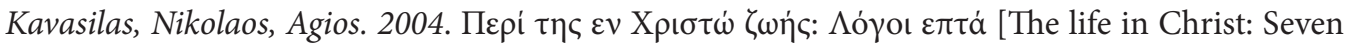
Orations]. Souroti Thessaloniki.

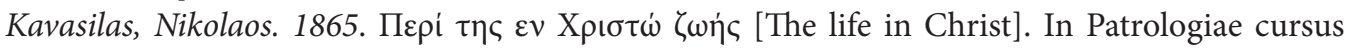
completus, edited by Jacques Paul Migne. Paris. Vol. 150, 493-725.

Kugea, C. 1909. Analecta Planudea. In Byzantinische Zeitschrift 18, 106-146.

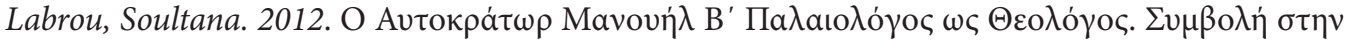

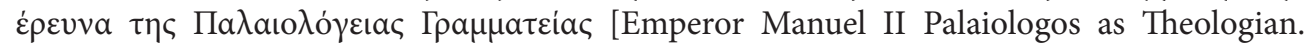
Contribution to the Research of the Palaiologan Literature]. Thessaloniki.

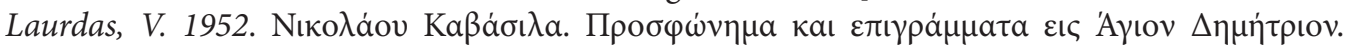

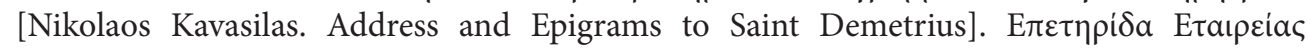

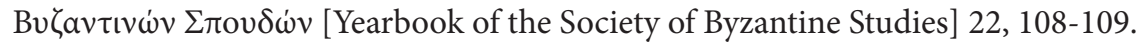

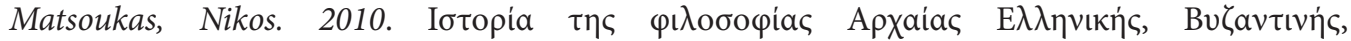

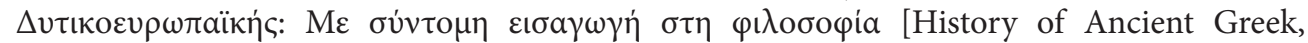
Byzantine, Western European Philosophy: With a Brief Introduction to Philosophy]. Thessaloniki.

Miklosich, Franz - Müller, Joseph.1862. Acta Patriarchatus Constantinopolitani. Volume 2, 27. Vindobonae.

Milko, Pavel. 2009. Úvod do byzantské filosofie. Červený Kostelec.

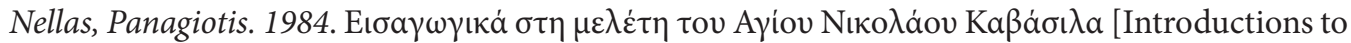

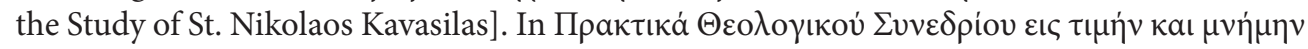

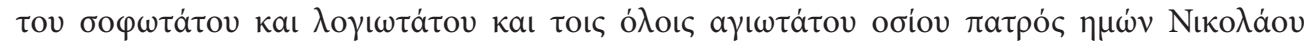

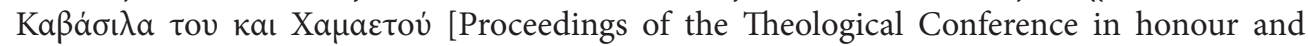
memory of the very wise and our Saint Father Nikolaos Kavasilas and Hamaetos]. Thessaloniki, 67-86.

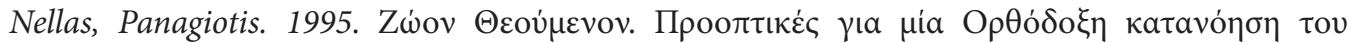
a $\theta \rho \omega \dot{\pi}$ ov [Zoon Theoumenon. Perspective for an Orthodox Understanding of Man]. Athens.

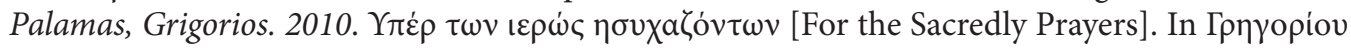

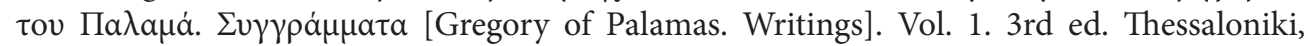
313-694.

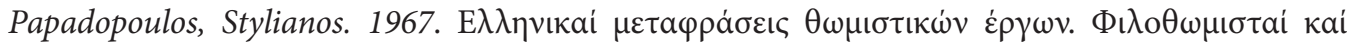

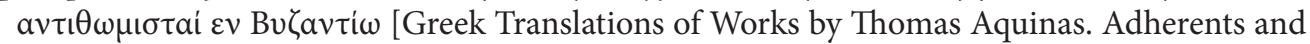
Opponents in Byzantium]. Athens.

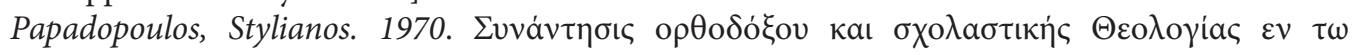

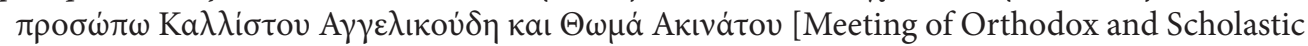
Theology in the Person of Kallistos Angelikoudis and Thomas Aquinas]. Thessaloniki.

Papaioannou, Stratis. 2013. Michael Psellos: Rhetoric and Authorship in Byzantium. Cambridge.

Rackl, Michael. 1924. Die griechischen Augustinusübersetzungen. Miscellanea Fr. Ehrle (Studi e Testi 37) I. Città del Vaticano, 1-35.

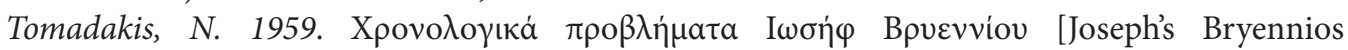

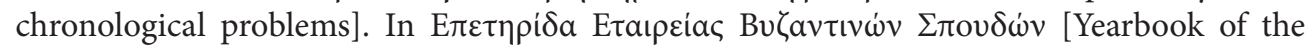
Society of Byzantine Studies] 29, 1-33. 
prof. ThDr. Ján Zozulak, PhD.

Constantine the Philosopher University in Nitra

Faculty of Arts

Department of Philosophy

Hodžova 1

94974 Nitra

Slovakia

jzozulak@ukf.sk

ORCID ID: 0000-0001-5263-1224

WOS Researcher ID: AAB-5533-2020

SCOPUS Author ID: 57204003830 